\title{
РАЗДЕЛ 1
}

\section{ИСТОРИЯ, ТЕОРИЯ И МЕТОДОЛОГИЯ ПРАЗДНИЧНОЙ КУЛЬТУРЫ}

УДК 323.215(470+571):379.8

DOI: $10.32340 / 2414-9101-2019-1-5-10$

Н. М. Андрейчук, кандидат педагогических наук, доцент Алтайский государственный институт культуры (Барнаул, Россия) sekletekeya@mail.ru

\section{ИСТОРИЯ И СОВРЕМЕННОСТЬ ГОСУДАРСТВЕННЫХ ПРАЗДНИКОВ РОССИИ}

\begin{abstract}
Аннотация. Представлена сравнительная характеристика эволюции функциональносимволического значения ряда общенациональных праздников России, присутствовавших в официальных календарях страны в разные периоды отечественной истории: имперский (дореволюционный), ранне-, поздне- и постсоветский. Изложен авторский взгляд на место праздника в системе инструментария советской антирелигиозной пропаганды и надэтнической (классовой) консолидации населения страны. Автор критически осмысляет манипулятивный потенциал массового праздника; предлагает ряд рекомендаций по раскрытии мемориального значения общегосударственных праздников современной России для населения страны.

Ключевые слова: государственный праздник, общенародный праздник, религиозный праздник, праздник иерковного (православного) календаря, общегосударственный праздник в иарской (дореволюиионной) России, общегосударственный праздник в Советской России, народные гуляния, массовые театрализованные праздничные формы, праздник в системе мероприятий советской антицерковной пропаганды, идеологическая сторона советского государственного праздни$\kappa a$, режиссура праздников, консолидирующая сила государственного праздника, общественные настроения, манипуляция сознанием.
\end{abstract}

Понятие «государственные праздники» может иметь весьма разное толкование и включать в себя праздники самой разной тематики и масштаба. Чаще всего к ним относят, во-первых, те праздники, которые отмечаются всей страной и дни их празднования объявляются выходными, а, во-вторых, праздники, посвящённые главным символам государства и его основному закону (например, День Государственного флага Российской Федерации, День Конституции). Данная статья посвящена тем праздникам нашего Отечества, которые в разные исторические эпохи были нацелены на формирование патриотических чувств, общественного настроения и единого гражданского мировоззрения своих подданных. Мы не ставим перед собой цель осветить историю и подробное содержание всех этапов развития таких празднеств, а, прежде всего, хотим взглянуть на эти празднества с позиций сценариста-режиссёра подобных празднеств нашей эпохи, эпохи начала третьего тысячелетия с целью осмысления и совершенствования своего творчества в данной сфере деятельности. Нами ставятся задачи увидеть, проанализировать и обобщить те способы эмоциональной выразительности праздничных действ, которые способствовали духовному единению наших предков, подтверждению свойственных им общественно-культурных отношений на разных этапах развития государства, оценить современные реалии в этой сфере празднеств, увидеть тенденции их развития и определить пути их совершенствования.

Выраженное отличие государственных праздников от общенародных праздников на Руси появилось лишь с эпохи царствования Петра І. До этого периода особых отличий не было. Разве что в ходе больших православных и народных празднеств цари и бояре демонстрировали власть и 
единство с церковью перед своими подданными с помощью торжественного выезда или выхода в народ в роскошных одеяниях и украшениях себя и своего окружения, публичного участия в церковных обрядах. Визуальные впечатления народа подкреплялись публичными провозглашениями царских милостей в честь праздника и публичной раздачей даров в виде угощений.

С началом царствования Петра ситуация изменилась. Презентация власти стала проходить по особым пышным и строгим ритуалам, которые были призваны максимально дистанцироваться от низших классов, не только подчеркивая божественное начало власти, но и его иноземное начало, возвеличивая эстетический и культурный идеал монарха, который также как и его окружение живет иной жизнью, нежели чернь. То есть если боярская Русь жила по единому праздничному месяцеслову, соблюдая общие с народом праздничные законы, то с эпохи Петра у знати появились свои обряды и ритуалы, которые всё дальше отодвигали власть от народа. Театрализация стала пронизывать всю жизнь царского двора. Серьёзное исследование, отражённое в двухтомном издании, торжественных праздничных церемоний русской монархии от времён правления Петра I до заката русской империи провёл американский историк Ричард С. Уортман, который использовал для описания индивидуальных способов презентации императорского мифа понятие «сценарии власти» [4;5].

Уортман хронологически продемонстрировал, как эти сценарии эволюционировали в зависимости от конкретного исторического контекста, как эти сценарии вводили конкретные события в символический контекст и видоизменяющийся церемониал освящал действия монархии в соответствии актуальными времени целями и задачами власти. В частности, в этой хронологии отражены ритуалы от торжеств государственного уровня царской эпохи времён освоения западных моделей жизни общества, эпохи барокко и Просвещения, национального самосознания, героизации образа государя до эпохи приспосабливания к революционным переменам общественного сознания. Представителя советского поколения наверняка удивит как много внимания уделялось в царское время пропаганде единства всех многочисленных народов России, поскольку советская пропаганда настаивала на том, что дореволюционная Россия была тюрьмой народов. Так в аллегорической балетной постановке хореографа М. Петипа на музыку Л. Минкуса «Ночь и День» единство российских народов демонстрировалось следующим образом: «Традиционный образ солнца репрезентировал монарха, который дарит всем свет и тепло. Духи ночи уступают место восхитительному дню с птицами, фонтанами и цветами, объявляющему о новом царствовании. Бабочки отделяются от роя и садятся на цветы. «Все народности Русского царства в разнообразных праздничных нарядах»-финны, грузины, донские казаки, сибирские шаманы, поляки - «соединяются для приветствования восходящего светила Дня». Каждая народность исполняет свой национальный танец, а затем все танцы сливаются в «один общий русский хоровод», центр которого образуют «самая красивая и полная женщина, то есть Русь». В заключении они сходятся вместе, а хор поёт славу «на небе солнцу красному», а «государю нашему на земле». Вечер завершился обычным исполнением гимна»[6, с. 311]. Традиционными в том историческом периоде были и многонациональные праздничные шествия по улицам столицы, в рядах которых можно было увидеть узбеков национальных халатах с дынями в руках, конных черкесов в бурках и т.д.

Если подобные сцены как-то перекликаются со сценами из праздников советской эпохи и нового времени, разве что в образе солнца монарха в своё время подменил Сталин, то описание продолжения праздника непривычно поражает нашего современника. Продолжил праздник всенародный пир на Ходынском поле, но это была не та печально знаменитая Ходынка, на которой произошла трагедия, спустя 13 лет, когда хотели повторить ниже описанное торжество: «Были накрыты столы на 400000 человек, а явилось более шестисот тысяч - огромное число участников даже для коронационного пира. Народ потчевали конфетами, печеньем, фигами, пивом и мёдом; присутствовавшим вручили коронационные кружки с царской печатью и датой «1883». На празднике были предложены многочисленные развлечения. Впервые на коронации действовал балаган - народный театр, привлекавший в 1860-е и 1870-е годы всё больше зрителей. Для организации праздника и развлечений был привлечён антрепренёр и импресарио М. В. Лентовский, основатель московских театров «Эрмитаж» и «Скоморох». Он предложил Коронационной комиссии сделать темой весеннего праздника «возрождение и расцвет весны, славы России и её народона- 
селения». Соответственно главным событием праздника было поставленная Лентовским в центральном амфитеатре Ходынского поля театрализованное аллегорическое шествие «Весна». В шествии участвовали популярные герои былин и лубочной литературы. Внимание зрителей было приковано к удивительной процессии, возглавляемой герольдами «с крылатыми латами, шишаками и длинными трубами», за которыми следовали «жук верхом и пешие жуки, кузнечик верхом и попарно пешие кузнечики и семь лягушек верхом». Царица пчёл ехала на колеснице-улье, за которой двигалась колесница русского богатыря Микулы Селяниновича - на её передней части «был помещён земной шар с изображением Российской империи». Микула был одет в костюм пахаря, вокруг его колесницы шли муравьи. В руках он держал огромный золотой плуг, упиравшийся в русскую землю. ... Микула олицетворял «чернозёмную силу». Согласно описанию в «Короновании их Императорских Величеств», Микула пользовался наибольшим успехом у публики. Далее шёл мужик в красной рубахе, держа ветку берёзы, за ним следовала колесница «Весны», на которой сидела изображавшая весну женщина, окружённая цветами и бабочками. Затем богатыри вели пленных. За ними на спине Змея Горыныча ехал одолевший его богатырь Добрыня Никитич. Последняя колесница в виде огромной бочки, изображала крестьянский праздник и называлась «Хмель», а на ней сидел изображавший хмель «разухабистый мужик»; на лошади сидел «подгулявший парень». За колесницей двигалась тройка со скоморохами, «шествие заключали коза с барабаном, медведь, журавль и русский хор с песнями и плясками»[6, с. 311-312]. Таким образом, мы видим, что подчёркивание важной роли простого народа в созидательной деятельности и российской истории в ходе проведения торжеств государственного уровня началось задолго до революционного октябрьского переворота. В советские времена подобные сцены называли бы «заигрыванием с народом», в современные - популизмом, однако, нельзя не заметить, что в последующие времена манипуляций человеческим сознанием с помощью массовых празднеств стало значительно больше, и они стали жёстче и целенаправленней, и направлены они были на расслоение, разделение общества, тогда как вышеприведённые, в чём-то наивные, театрализованные сцены свидетельствуют о желании объединить общество.

Массовые государственные празднества эпохи СССР достаточно широко освещены в литературе и научно осмыслены. В ряду их исследователей имена А. И. Мазаева, Д. М. Генкина, И. Г. Шароева, А. И. Чечётина, В. С. Аксёнова и др. И хотя эти исследования проводились в советскую эпоху и служили диктуемым партийным установкам того времени, в них достаточно глубоко проанализирована общая картина и основные сценарно-режиссёрские приёмы в организации массовых действ в дни государственных торжеств. «Массы»- пожалуй, самое любимое слово в лексиконе В. И. Ленина - «народные массы», «трудящиеся массы», «воздействие на массы», «деятельность масс» и т. д. «Массы масс»- съязвил по этому поводу Н. Эрдман. Театрализованные праздничные формы того времени тоже были массовыми - массовые инсценировки, балаганы, карнавалы, митинги, шествия, гуляния... Вовлечение широких масс трудящихся в праздничные революционные действа, активизация самодеятельности масс являлись важнейшей задачей организаторов празднеств, поскольку активное практическое участие большого числа людей в подобного рода событиях многократно увеличивало эффект внедрения в их сознания новых идей и умонастроений. В первую очередь объектом целенаправленной большевистской агитации и пропаганды стало подрастающее поколение, с помощью которого внедрялись новые праздники Красного календаря, ликвидировались старые праздничные традиции, пропагандировались актуальные политические установки. Вот типичные праздничные лозунги той эпохи - «Да здравствует Труд, новый великий обряд Красного праздника - выше священных обрядов буржуев и попов!», «Рабочие и трудящиеся, сплачивайтесь вокруг ВКП, руководителя социалистического строительства!», «Бойкот лодырю и прогульщику! Первомайский привет передовикам социалистического соревнования!» и т. д.

Если православные и монархические мотивы главенствовали во всех российских праздниках дореволюционной эпохи, то в советскую эпоху церковь не просто была отделена от государства, со всем церковным, в том числе и с церковными праздниками велась ожесточённая борьба. Так в 1929 году, когда празднование Пасхи выпало на первые майские дни, повсеместно прошли первомайские торжества под лозунгом «Долой Пасху! - Да здравствует 1 Мая!». А к пасхальной ночи готовились специальные мероприятия. Так в Твери культпросветчики организовали 
художественный карнавал под названием «Штурм богов», начавшийся с коротких антипасхальных митингов. Вот как описывал этот «Отличный монтаж клуба им. Томского» журнал «Культурная революция»: «Золотой мешок, освещённый электрическими лампочками. От него провода, держась за которые, волокутся раввин, ксёндз, пастор, мулла. И только синий цвет прожектора помогает разглядеть под маской этих «торговцев опиумом» задорные, со смешинкой, комсомольские глаза.

Дальше - «чудо». Из глаз какой-то «богородицы», при свете карболитовых фонарей, бегут струйки слёз, а сзади огни факелов обнажают нехитрую механику слезоточивой «заступницы»пара бутылок с водой, две стеклянные трубки. И всё. Смешно и просто. А давно ли с трудом нажитые деньги клались к ногам вот таких «чудотворных» слезоточивых икон, и пухли монастырские сокровищницы.

Сотни фигур, монтажи, бородатые святые, Иисус Христос - смешались в пёстрое карнавальное зрелище.

И когда брякнули колокола, площадь зашевелилась и под гром оркестра, бодро чеканя шаг, двинулась демонстрация на Советскую площадь. Казалось, вышло из берегов шумное озеро и потом устремилось туда, где во мраке ныли церковные колокола...

Карнавальное шествие продолжалось до 12 часов ночи, после чего все участники собрались на Советской площади, где был устроен «штурм богов»- сожжение куличей, пасхи, других принадлежностей церковного ритуала» [2].

Чуть ли не единственную серьёзную попытку научного анализа массовых государственных праздников в СССР с позиций уже постсоветского периода сделал в своём исследовании немецкий учёный Мальте Рольф, который выпукло продемонстрировал целенаправленный идеологический диктат правящей коммунистической партии в манипуляции человеческим сознанием, способы формирования «коллективного восторга» трудящихся советских масс в ходе праздничных шествий. Задолго до Рольфа об этом писали другие авторы, наши соотечественники из дальнего зарубежья. Среди них и классик советского массового революционного «театра улиц» Н. Н. Евреинов, автор теории театрализации жизни, который эмигрировав во Францию, написал в 1939 году пьесу, в которой вложил в уста одного из персонажей яркий монолог о преступной театрализации самой советской власти, где актёрствовать стали «почти все, начиная со Сталина... Вглядитесь только, что сейчас происходит на подмостках России! - все власть имущие действуют под псевдонимами, словно в театре, ходят в масках, потайными ходами, притворяются верноподданными её величества Партии и пресмыкаются перед её вождями, которых норовят стащить за ногу и сбросить в подвалы Лубянки. Всюду одна лишь комедия: комедия служения народу. Комедия обожания вождей! Комедия суда и принесения повинной! Комедия, наконец, смертной казни! Какая-то беспардонная игра в театр или кровавая мелодрама, какие сочинялись в прежние времена, на потеху черни! - Вот, что такое наше теперешнее житьё-бытьё ». В те же годы русский эмигрант В. Набоков в одном из своих рассказов писал о том, что поклонение власти большинства, демонстрируемое на массовых советских праздниках на деле подразумевает под идолом большинства вовсе не социологическое понятие «ибо большинство, это он (Сталин - Н. М.)». Ёмко и едко выразил этот способ манипулирования демонстрацией волеизъявления народа поэт Д. Самойлов:

Иду домой с собранья,

Окончилось как раз,

Мурлычу то, что ранее

Мурлыкалось не раз:

Свободу не объявят

И денег не дадут,

Надуют и заставят

Кричать, что не надут.

Вместе с тем, признавая правоту вышеприведённых суждений, мы должны обратить внимание на то, что массовые празднества начала советской эпохи рассматривались доселе только с двух антагонистических позиций: за и против. Тогда как советская эпоха это не только эпоха диктатуры марксистско-ленинской идеологии, но и радостного торжества подлинных побед 
и свершений нашего народа. Так, к примеру, пионеры - это не только павлики морозовы, но и тимуровцы, комсомольцы, это не только участники формальных «собраний-чисток», но и молодогвардейцы, и строители новых городов, и т. д. Символами советской эпохи стали пионерские слёты и пионерские костры, фестивали комсомольских и бардовских песен, ликующие торжества в честь Великой Победы и полёта Гагарина, чествования простых тружеников-созидателей, торжественные церемониалы у могилы неизвестного солдата и военные парады, молодёжные фестивали, Олимпиада 1980 года, праздничные традиции 8 марта и 1 сентября и т. д. История советской эпохи многомерна и неоднозначна, и это история нашей Родины. Массовые праздники призваны объединять людей этим общим чувством принадлежности к нашей биографии - биографии нашего Отечества со всеми бедами, радостями, взлётами и принятию своей принадлежности к нации, которой есть чем гордиться. «И не думать об этом нельзя/ И не помнить об этом не вправе я/ Это наша с тобою судьба/ Это наша с тобой биография/»-данные строки могут стать эпиграфом по сути к любым государственным праздникам, которые непременно базируются на исторической памяти народа. Проблема в том, что, к сожалению, социальные катаклизмы в нашей стране приводили к тому, что отсчёт этой памяти начинался всякий раз заново. В туже советскую эпоху не осталось ни одной праздничной даты из дореволюционного периода.

О. Л. Орлов, посвятивший своё докторское исследование российскому празднику как историко-культурному феномену [7], обратил внимание на следующую особенность праздничного календаря советского периода отечественной истории - того гражданского звучания, которое могло бы быть содержательно и эмоционально не чуждо нашему времени - обилие праздничных дат, посвящённых военным победам России. Таких дат он насчитал более десятка, при этом, большинство этих значимых для наших предков из этих событий нашими современниками не только торжественно не отмечаются, но и, по сути, вне учебников истории, основным населением забыты. Тогда как в те же царские времена конца XIX века в Петербурге эти победы пропагандировались на театрализованных представлениях на открытом воздухе. Десятки тысяч людей собирали такие постановки как «Взятие Азова», «Синопский бой», «Война с Турцией», «Взятие Плевны». Приёмы режиссёра-постановщика этих массовых зрелищ, активно использовавшего природный ландшафт парков, прудов и рек, А. Я. Алексеева-Яковлева одно время называли устаревшими, мол, где ему до возможностей кинематографа. Однако сегодня в нашей стране вновь стал пробуждаться интерес к реконструкции исторических событий, многие из них весьма интересно воплощены, но по смелости, масштабности и эмоциональной выразительности до постановок более чем вековой давности им далеко.

Насущной необходимостью является задача «соединить эпохи» в главных российских праздниках сегодняшнего дня. Первые шаги к этому - не только возрождение исконных российских праздников народного и православного календаря, но и, в частности, внесение в современный праздничный календарь России в 2004 году Дня Единства, истоки которого лежат в нашей истории четырёхвековой давности. Вместе с тем, подавляющее число граждан не имеют сколь-либо внятного представления о содержательной основе этого праздника - изгнания из Москвы интервентов русским народным ополчением в 1612 году. К сожалению, праздничные традиции не сформированы и вокруг этого праздника, и праздника Дня России. По сути, на сегодняшний день они являются для большинства населения просто датами, дополнительными выходными днями. На наш взгляд, чтобы поднять их над буднями, нужна целенаправленная работа по осмыслению сути и содержательной наполненности этих праздников, поисков их символической образности, а главное, стимулирование поиска новых художественно-образных решений содержательного наполнения, поскольку праздник живёт только тогда, когда вокруг него живёт творчество.

В заключение, сделаем следующие выводы:

- на всех этапах развития российского государства массовые праздники использовались в целях пропаганды незыблемости идей существующего строя на том или ином этапе исторического развития;

- массовые праздники во все времена требуют непосредственного участия, а не только непосредственного смотрения, поэтому содержательная сила их психологического воздействия на человека превышает мощь любых средств массовой информации, вследствие чего 
государственные праздники являются сильнейшим фактором сохранения и формирования основополагающего и объединяющего мировоззрения своих граждан, их консолидации и укрепления их единства;

- в современной сценарно-режиссёрской деятельности по организации массовых государственных празднеств уделяется недостаточное внимание эмоционально-выразительным возможностям использования природной, исторической и архитектурной пространственной среды празднеств, тогда как ориентация на эти возможности многократно усиливает эффект непосредственной сопричастности к истории родной земли у членов празднующего сообщества;

- новые ритмы современности требуют новых выразительных средств и новых выразительных эффектов в организации массовых празднеств, вместе с тем, без целенаправленного использования исторических ретроспекций в организации массовых действ современных государственных праздников эти праздники не только теряют свой содержательный потенциал, но, главное, теряют потенциал мощной объединительной силы, которая базируется на исторической памяти народа о победах предшествующих поколений своего Отечества. Поэтому в сценарно-режиссёрские замыслы по организации массовых государственных празднеств необходимо более интенсивно вводить сцены, в которых в символической форме отражались бы воспоминания о радостях великих побед своих соотечественников в разные эпохи становления страны.

\section{Список литературы}

1. Аксёнов, В. С. Организация массовых праздников трудящихся (1918-1920) : учеб. пособие. - Ленинград : [б. и.], 1974. - 76 с.

2. Как мы провели первомайскую неделю // Культурная революция. - 1929. - № 10. - С. 35.

3. Рольф, М. Советские массовые праздники. - Москва : Рос. полит. энцик., 2009. - 439 с. (История сталинизма).

4. Николай Евреинов // Анненков, Ю. Дневник моих встреч: цикл трагедий : в 2 т. - Москва : Худож. лит., 1991. - Т. 2. - С. 111-142.

5. Уортман, Р. С. Сценарии власти. Мифы и церемонии русской монархии : в 2 т. - Москва: ОГИ, 2004. - Т. 1 : От Петра Великого до смерти Николая I. - 605 с. : ил. - (Классическая мысль).

6. Уортман, Р. С. Сценарии власти. Мифы и церемонии русской монархии : в 2 т. - Москва : ОГИ, 2004. - Т. 2 : От Александра второго до отречения Николая II. - 796 с. : ил. - (Классическая мысль).

Nina M. Andreychuk, Ph. D. in Pedagogics, Associate Professor Altai State Institute of Culture (Barnaul, Russia) sekletekeya@mail.ru

\section{OFFICIAL HOLIDAYS IN RUSSIA: HISTORY AND MODERNITY}

\footnotetext{
Abstract. The paper outlines comparative analysis of evolution of functional and symbolic meaning of Russian national holidays that were enlisted in official calendars of the country in various epochs of native history: imperial (prerevolutionary), early Soviet, late Soviet and post-Soviet time. The author states her own view on a place of a holiday in system of Soviet antireligious propaganda, and in context of measures for supra-ethnic (class) solidarization of the country population. The author critically understands manipulative potential of a mass holiday; she offers a number of recommendations for disclosing memorial meaning of wide-national holidays for the today's Russia's population.

Keywords: an official holiday, a national holiday, a feast, an Orthodox holi-day, a national holiday in Czarist (prerevolutionary) Russia, a national holiday in Soviet Russia, outdoor festivities, mass theatrical forms of festives, a holiday in of Soviet antireligious propaganda, ideological aspect of a Soviet official holiday, holidays-making, consolidative force of a public holiday, public opinion, mind control.
} 